\title{
Marketing e Educação Política: um estudo sobre agentes, estratégias e interpretações da cultura
}

\author{
Elias Evangelista Gomes' \\ Maria da Graça Jacintho Setton" \\ 'Universidade Federal de Alfenas (UNIFAL-MG), Alfenas/MG - Brasil \\ "Universidade de São Paulo (USP), São Paulo/SP - Brasil
}

RESUMO - Marketing e Educação Política: um estudo sobre agentes, estratégias e interpretações da cultura. O objetivo deste artigo é refletir sobre o marketing político como instância cultural e socializadora capaz de oferecer uma educação política para amplos segmentos da população. Com suas estratégias comunicacionais, os profissionais da área são potenciais produtores, difusores, mediadores e consagradores de ideias acerca da política, do povo e da nação brasileira. $\mathrm{O}$ artigo propõe discutir algumas estratégias dando destaque aos mecanismos utilizados para orientar percepções acerca dos vínculos sociais entre os agentes da política, com destaque para os candidatos e os eleitores. Trata-se de um esforço de precisar as relações indissociáveis entre a sociologia da educação e a sociologia da cultura. Palavras-chave: Marketing Político. Educação Política. Cultura. Socialização. Agentes Socializadores.

ABSTRACT - Political Marketing and Education: a study on agents, strategies and interpretations of culture. The objective of this article is to reflect on political marketing as a cultural and socializational instance capable of offering political education to diverse population segments. Given their communication strategies, marketing professionals are potential producers, disseminators, mediators, and authorities on ideas relating to politics, the people and the nation of Brazil. This paper aims to examine strategies with an emphasis on mechanisms used to influence perceptions regarding social bonds between political agents, focusing primarily on candidates and voters. This article aspires to elucidate the indivisible relation between the sociology of education and the sociology of culture.

Keywords: Political Marketing. Political Education. Culture. Socialization. Agents of Socialization.

Educação \& Realidade, Porto Alegre, v. 41, n. 3, p. 853-872, jul./set. 2016. 853 http://dx.doi.org/10.1590/2175-623651728 


\section{Introdução}

O objetivo deste artigo é refletir sobre as relações entre o marketing político como uma emergente e potencial instância socializadora midiática e os processos de constituição de noções, ideias e concepções acerca dos vínculos sociais entre agentes no seio da política no Brasil. Trata-se de uma reflexão que se ocupa em pensar a comunicação política como instituição social construtora de sentidos. Acredita-se que, através desta análise, é possível identificar parte dos processos de produção, difusão, transmissão e negociação de valores de ordem simbólica que colaboram para a construção de representações sobre as formas de se fazer política no país ${ }^{1}$.

Florestan Fernandes (1960; 1971) aponta que a sociologia da educação é parte da sociologia do conhecimento, que por sua vez é uma das páginas da sociologia geral. A partir dessa concepção, julga-se que a análise dos fenômenos educativos não deve se restringir aos marcos disciplinares demasiadamente restritos e fragmentados. Assim, mais precisamente, este artigo busca responder aos seguintes questionamentos: qual o papel desempenhado pelos consultores de marketing para parcela da educação política no Brasil? Quais estratégias de produção, difusão, transmissão e negociação utilizam para elaboração dos materiais midiáticos? Como representam os vínculos sociais entre os candidatos e os eleitores?

Para responder a estas questões, parte-se do pressuposto de que a sociologia da educação constrói interfaces precisas com aspectos da sociologia da cultura e do poder. Como diria Pierre Bourdieu (1991),

[...] a sociologia da educação é um capítulo, e não dos menores, da sociologia do conhecimento e também da sociologia do poder - sem falar da sociologia das filosofias do poder. Longe de ser este tipo de ciência aplicada, portanto inferior, e adequada somente para os pedagogos, que se acostumaram a vê-la dessa forma, ela se situa na base de uma antropologia geral do poder e da legitimidade (Bourdieu, 1991, p. 117).

Nesta direção, com base em uma inspiração maussiana, Maria da Graça Jacintho Setton (2012) compreende a socialização como um fato social total, um fenômeno geral e generalizado, considerando-a em sua dinâmica relacional, econômica, moral, estética e política. Cumpre salientar que esse apontamento sociológico é fundamentado em uma outra constatação, ou seja, no mundo contemporâneo, especialmente urbano, o processo de formação social dos indivíduos ocorre a partir de uma interdependência de propostas pedagógicas de instâncias sociais e agentes (Setton, 2002).

Inspirando-se nas considerações acima, acredita-se que a sociologia da educação, na condição de disciplina interessada no estudo dos processos socializadores, deve se ocupar em investigar e analisar 
todos os aspectos da formação das maneiras de ser, agir e pensar dos indivíduos. Neste artigo, o foco se localiza na instituição do marketing político. Em um universo social em que as mídias - e dentre elas a publicidade política - assumem uma relevância expressiva (Setton, 2004; 2012), cumpre debruçar-se sob o desvelar de suas estratégias pedagógicas bem como os conteúdos divulgados pelos profissionais em questão.

Em termos formais, o marketing pode ser compreendido como uma função organizacional, baseada em um conjunto de processos que envolvem a criação, a comunicação e a difusão de um estoque de valores e significados sociais, bem como a administração do relacionamento entre a organização comercial e um determinado público, na perspectiva de beneficiar tanto um quanto o outro. Contudo, desde a década de 1950, especificamente, o marketing político compreende as ações de comunicação de partidos políticos e de candidatos antes, durante e depois do período eleitoral (Figueiredo, 2000).

Corroborando esses pressupostos, Neusa Damartini Gomes (2000) considera que as campanhas eleitorais são formas persuasivas de comunicação política que, em maior ou menor grau, de acordo com o contexto, operam como: a) meios de educação cívica; b) meios de legitimação do sistema político e justificativa democrática; c) meios de fixação dos temas de interesse político e difusão dos símbolos políticos; d) meios de seleção e recrutamento de pessoal político; e) meios de transparência da ação política dos candidatos e dos partidos. Para a autora, desde a redemocratização, o Brasil conta com eleições obrigatórias a cada dois anos, sendo que, de maneira contínua e difusa, depreende-se um acúmulo de mensagens e repertórios simbólicos acerca do país e de seu povo.

Seguindo este argumento, os profissionais de marketing político não vendem apenas candidatos; vendem também representações sobre racionalidade, organização e estratégias de comunicação que fazem uso. Associam eficácia eleitoral à boa comunicação e à boa imagem e à contratação de experientes profissionais (Scotto, 2004). Ao mesmo tempo, os profissionais de marketing político são habilidosos na construção e no acúmulo de um conjunto de imagens reveladoras de um entendimento sobre a vida e a atividade política auxiliando na tarefa de uma educação cívica e moral de amplos segmentos da população.

Originado nos Estados Unidos, o marketing político ganhou força na maior parte do mundo e pode ser considerado um dos principais vetores de elaboração e orientação de concepções propagadas em relação à política contemporânea. Acompanhando essa tendência no Brasil, destaca-se aqui, entre muitas formas de expressão, o Horário Gratuito de Propaganda Eleitoral (HGPE), momento que antecede ao sufrágio, como um espaço de construção de narrativas a respeito da conjuntura local, regional ou nacional, imagens do povo brasileiro e o lugar da política em nossas vidas. 
Por fim, considera-se que o marketing político possui, junto com outros espaços educativos, como a família, a escola e a religião, uma força socializadora, na medida em que faz uso de um conjunto de estratégias para a produção e a difusão de conteúdos, numa diligente interação entre candidatos e eleitores; mais do que isso, os consultores do marketing possuem uma centralidade e uma legitimidade neste processo, podendo ser considerados filtros de uma interpretação do social e da cultura política em constantes e decisivos momentos da história. Assim sendo, busca-se compreender as estratégias desenvolvidas por eles tanto no que se refere ao esforço de interpretar os interesses do eleitorado quanto no empenho em difundir mensagens políticas e sobre formas de se fazer a política e se relacionar com ela e com os seus agentes. Trata-se de um relevante agente social, com visibilidade e capacidade de tornar público um conjunto de símbolos, agindo muitas vezes como intérpretes do país, de seu povo, demandas e desafios.

Como base empírica, o artigo conta com análises de um trabalho de campo que compreendeu: a) entrevistas com seis consultores de marketing político das campanhas presidenciais do Brasil entre 1989 e 2010; b) análises de livros e materiais de mídia produzidos e publicados por eles; c) etnografia em uma campanha para prefeito da cidade de Belém, capital do estado do Pará, em 2012, na qual foram observadas - c.1) atividades de rua dos candidatos, c.2) debates na televisão, c.3) elaboração do programa de governo, c.4) acompanhamento de gravação e produção dos programas eleitorais no primeiro e segundo turno das eleições de 2012, c.5) entrevistas com profissionais do marketing político, com experiência nacional, mas também atuantes na região amazônica² .

Por fim, a partir da análise deste conjunto de dados, foi possível destacar como estratégias educativas do marketing político: a) a mediação entre profissionais do marketing e eleitores a partir da técnica da pesquisa qualitativa com interesse nas demandas da população; b) a força do comício eletrônico nas campanhas eleitorais - o dar, receber e retribuir; c) bem como a capacidade de revelar valores nacionais - aqui se destacando a religiosidade, num evidente e eficiente trabalho de socialização. Por fim, no projeto didático da educação política no Brasil, observa-se que o conjunto de estratégias discutido neste artigo tem como finalidade difundir noções e orientar posturas acerca dos vínculos sociais entre os eleitores e os candidatos.

\section{A Consolidação de um Tipo Específico de Intérprete da Cultura}

Notadamente, no caso das eleições brasileiras, nas três últimas décadas, com a abertura democrática - pós-ditadura militar - vê-se a emergência de um tipo de profissional, ou melhor, um conselheiro profissional que passa a ter um espaço crescente e decisivo ${ }^{3}$. Acompanhado de um staffigualmente capacitado, esse profissional conta com a cola- 
boração de uma série muito variada de outros profissionais: fotógrafos, jornalistas, publicitários, cineastas, designers, sociólogos, cientistas políticos, antropólogos, psicólogos, comunicólogos, radialistas, especialistas em tecnologia da informação, que em conjunto elaboram estratégias de difusão de um tipo especial de mensagem com a finalidade de persuadir a população, estimular consensos e orientar o voto. Embora cada qual na sua função contribua para a construção das candidaturas, destaca-se a figura deste expert ou coordenador da intelligentsia de uma campanha eleitoral.

Seguidamente, tem-se denominado esse profissional como marqueteiro. Trata-se de um agente que orienta e direciona as ações de comunicação política de candidatos, partidos e governos. Não menos raro, observa-se a repulsa ao termo, sugerindo que tal denominação desqualifica o trabalho desenvolvido. Alguns preferem outras denominações, tais como profissionais do marketing, comunicadores, publicitários, estrategistas e consultores políticos. Esta polêmica, longe de ser uma questão meramente terminológica, está circunscrita nas disputas de representações e processos de busca de legitimação profissional (Scotto, 2004). Tudo isso, combinado a uma estratégia de publicidade da própria atuação, visa reduzir a rejeição de segmentos sociais que os qualificam como manipuladores do conteúdo político (Castilho, 2014a). Para os interesses dessa discussão, a forma como o denominamos não é relevante em si. Cumpre refletir sobre o papel que ocupam na formação dos consensos sociais, ou mais especificamente, sobre o papel que ocupam na educação política no Brasil nos últimos anos.

Os agentes do marketing político conseguiram vender seus conhecimentos como um produto insubstituível não somente para as eleições, mas também para o sucesso dos governos e das administrações públicas. Políticos e partidos, por vezes, sentem-se em risco ao atuarem sem a presença de um desses profissionais. Recorrentemente, os consultores políticos informam que comunicação não é o que se diz, mas o que o outro entende. Com isso, dizem que os políticos conhecem a política, porém, nem sempre sabem se comunicar com os eleitores e os cidadãos. Esta constatação impõe uma insegurança às instituições e aos atores políticos de modo que os tornam quase dependentes dos profissionais de comunicação para o sucesso eleitoral.

Em outros termos, esses profissionais constroem uma representação acerca de si mesmos como estrategistas competentes para a transmissão de interpretações adequadas à realidade, e coerentes com as percepções dos eleitores, bem como a seleção de conteúdos pertinentes à conjuntura política e à opinião pública. Mas, é possível enquadrá-los ainda como agentes educativos por operarem um conjunto de noções, valores e conteúdos com vistas a orientar as percepções e as ações dos eleitores. Atuam na preparação de disposições de cultura em seu aspecto político; são responsáveis ainda por uma didática própria do marketing midiático, consumidor de referenciais e linguagens presentes em 
Marketing e Educação Política

outras instâncias sociais, dentre elas a própria mídia e os programas de entretenimento.

Parte-se da hipótese de que esses consultores, chefes das equipes de marketing político, em especial aqueles de maior visibilidade e influência sobre a área profissional, poderiam assumir a posição de intérpretes da cultura; como produtores de mídias, de modo crescente nos últimos anos, visam influir sobre certos modos de ser, pensar e agir dos cidadãos no âmbito da política no Brasil. Não é sem fundamento que, ao estudar escritores da literatura brasileira, Renato Ortiz (2006) afirma que a problemática da cultura tem sido, até hoje, uma questão política. Segundo ele, a noção de identidade nacional deve ser vista como uma construção simbólica resultante de recortes arbitrários, ligada a uma reinterpretação do popular pelos grupos sociais e à própria imagem do Estado brasileiro. Ortiz revela que alguns escritores contribuíram para a consolidação de noções sobre o povo e a nação. Conclui que eles ocuparam o papel de mediadores simbólicos, confeccionando uma ligação entre o particular e o universal, o singular e o global, e acabaram por elaborar uma reinterpretação simbólica.

Seguindo esse raciocínio e tendo esse histórico de análise sobre os intérpretes da cultura brasileira, compreende-se que, no contexto atual do país, os consultores de marketing político atuam com uma prática semelhante aos intérpretes da cultura, no âmbito local, regional e nacional, desenvolvendo e assumindo um caráter formativo acerca da política. Considera-se que tais agentes, ao produzirem e difundirem representações sobre o Brasil, representações sobre um estado ou município e ou suas instituições, estão, ao mesmo tempo, difundindo formas de pensamento, categorias de análise e julgamento que são, nas palavras de Pierre Bourdieu (2001), formas de pensar a nação e suas formas de viver a política. De certo modo, estariam atuando de maneira continua e homeopática, a cada nova eleição, na difusão de crenças e ou consensos acerca do país e das formas de se fazer política e se relacionar com ela e com os seus agentes.

\section{A Estratégia da Mediação através da Pesquisa de Opinião}

No primeiro turno da eleição de 2012 para prefeito de Belém, na campanha de Edmilson Rodrigues candidato do Partido Socialismo e Liberdade (PSOL), por falta de recursos para financiamento em todas as frentes, decidiu-se que as atividades de consultoria em pesquisas de opinião pública seriam pontuais e não abarcariam todos os aspectos da campanha como análise de peças, programas e materiais ${ }^{4}$. Contudo, naquele processo eleitoral, observou-se atividades de pesquisa de opinião pública realizadas por uma socióloga experiente em pesquisas qualitativas responsável por analisar a recepção e as reações dos eleitores quanto às performances dos candidatos ${ }^{5}$. 
Nas campanhas, as pesquisas qualitativas podem ocorrer por meio de observação e análise de opinião de pessoas em localidades e situações específicas, porém o modo mais convencional tem sido por meio da técnica de grupos focais. São reunidos grupos de eleitores, selecionados e separados a partir de marcadores sociais da diferença, dentre eles, classe, idade, gênero, religiosidade, região, profissões, escolaridade, raça. Esses grupos são reunidos em salas de agências, escritórios ou hotéis, um espaço neutro, sem menção aos símbolos das campanhas. Na maior parte das vezes, os participantes não têm conhecimento acerca de qual campanha os convidaram, de modo que suas posturas não sejam uma resposta automática à simpatia ou à repulsa que têm originalmente aos candidatos e aos partidos contratantes da pesquisa.

Além da suposta neutralidade técnica dos critérios e formatos dos grupos focais, os consultores políticos preocupam-se em buscar profissionais com formação e experiência de pesquisa de opinião pública e de mercado. Buscam com isso evitar o erro amostral, descritivo ou interpretativo capaz de distorcer resultados e contribuir para a falta de sintonia entre a campanha e o eleitorado que, consequentemente, conduziria ao prejuízo do contratante da pesquisa; tanto o candidato perderia a eleição ou a legitimidade, bem como o consultor teria seu prestígio abalado ao guiar a campanha para uma direção equivocada.

No trabalho de campo e na literatura produzida pelos consultores, observou-se um discurso que ressalta a não passividade do eleitor diante das estratégias comunicacionais das campanhas. Para além do entendimento de que o eleitor é socializado por diferentes instâncias educativas, o que torna a atividade do marketing mais complexa, tal discurso contribui para a consolidação da profissão, buscando tornar necessária a contratação de pessoal especializado.

No que tange aos coordenadores de marketing político, embora recorram aos profissionais diversos, tais como cientistas sociais, psicólogos, pedagogos, comunicólogos, dentre outros, no que concerne ao recolhimento de dados sobre opinião pública, chamam para si a prerrogativa de interpretação dos dados. Eles são agentes capazes de fazer a mediação sazonal e temporária entre os indivíduos e as instituições, entre o conteúdo político e o método de atingi-lo. Uma mediação que visa romper o abismo que separa os eleitores, os partidos e os candidatos, bem como aproximá-los, pelo menos nos momentos das eleições. Eles atuam como coordenadores gerais, mestres ou conselheiros do processo de mediação e da ligação entre a produção e a recepção de um repertório de ideias. Como diria Ortiz (2006), trabalhariam na construção simbólica de uma interpretação interessada de Brasil filiada a grupos sociais visando unificar percepções acerca do povo.

No âmbito dos meios de comunicação atuais, existe o desafio de não só tentar comercializar produtos antigos de maneiras novas, mas de acompanhar as mudanças do conteúdo e das funções dos mesmos 
Marketing e Educação Política

(Dizard, 2000). Parece que, na política, o marketing tem sido fundamental para essa adequação de realidades. Porém, não se trata de uma adequação total, porque, como veremos, são recorrentes os usos de valores tradicionais ligados à afetividade, gênero, família, religião para afirmar que, embora existam novidades nos candidatos, eles estão ligados a valores historicamente legítimos ${ }^{6}$.

As pesquisas quantitativas e qualitativas nas campanhas eleitorais não apenas contribuem para adequação das imagens dos candidatos e elaboração das estratégias. Contribuem ainda para a elaboração da noção de racionalidade e previsibilidade do processo, bem como, possibilitam que o marketing político construa sua autorrepresentação de cientificidade (Scotto, 2004). Por outro lado, tais pesquisas tornam as campanhas eleitorais pasteurizadas, pois fazem uso daquilo que tem maior potencial de sucesso. Auscultando os eleitores e as suas demandas, os candidatos não se arriscam, fazem das campanhas um espaço de consensos ou de ideias majoritárias da população, nem sempre apresentando propostas e ou medidas para suas realizações, tornando aquele espaço de visibilidade pouco político ou de enfrentamento ideológico.

Por entenderem que o brasileiro é um sujeito experiente em televisão, os consultores políticos buscam adequar ainda seus candidatos aos padrões midiáticos legítimos e reconhecidos. Numa aproximação ao entretenimento televisivo, as pesquisas de marketing político contribuem para suavização do debate político e para que as tensões capazes de elevar a temperatura dos humores eleitorais não fiquem evidentes. Transformam o momento eleitoral em um espaço anódino, sem explicitar os projetos, as políticas de Estado, as complexidades e as maneiras de alcançá-las. Por certo, essas afirmações não são novidades, contudo vale explorar as formas de uma possível superação, a partir de seu desvelamento.

A exemplo disso, frente aos consensos que imperam entre os profissionais do marketing político, observa-se certa divergência quanto ao uso das pesquisas eleitorais. Na maior parte, há uma crença de que as pesquisas de fato podem orientar melhor o trabalho de comunicação política e colocar o candidato e as instituições em permanente sintonia com os eleitores. Porém, confirmando o argumento acima exposto, observou-se um caso mais expressivo do questionamento ao uso das pesquisas. Francisco Cavalcante, que estudou filosofia, é escritor e publicitário, dono da Agência Vanguarda e atuou junto ao Partido dos Trabalhadores (PT) tanto no âmbito nacional quanto regional, Partido Trabalhista Brasileiro (PTB) e Partido Socialismo e Liberdade (PSOL) no Pará e Amapá, concorda que as pesquisas podem perceber os gostos e os interesses dos eleitores. Entretanto, acusa a artificialidade de candidaturas diante do uso exagerado das pesquisas. Para ele, o partido e o candidato podem ter um programa em sintonia ou não com a maioria

860 Educação \& Realidade, Porto Alegre, v. 41, n. 3, p. 853-872, jul./set. 2016. 
da população, pois nem sempre aquilo que o candidato e o partido estão a pensar é o que a população pensa. Em seu entendimento, a função do partido é também construir opiniões junto à sociedade. Se as campanhas apenas se pautam pela opinião pública e os resultados de pesquisas quantitativas e qualitativas, não superam o senso comum, deixam de educar a população e fazê-la pensar diferente enriquecendo as suas reflexões. Para Cavalcante, a pesquisa tem um foco mais preciso: testar peças e materiais para checar se de fato o eleitorado compreende a mensagem que foi transmitida.

A crítica desse consultor faz-nos lembrar a preocupação didática de professores ao levar em consideração a bagagem anterior dos educandos. Contudo, é também tarefa dos bons educadores contribuir para a formação e a ampliação de conteúdos a fim de garantir um efetivo processo educacional. Sem acréscimos, sem novas proposições, utiliza-se de forma demagógica um importante recurso didático que poderia balizar e favorecer a aprendizagem de elementos do currículo de uma educação política. No caso das eleições, utilizar as pesquisas de opinião pública apenas para dizer aquilo que os eleitores querem ouvir sem crítica, tensão, polêmica e enfretamentos, constitutivos do fazer político, de fato pouco contribui para a construção de uma democracia representativa.

Assim sendo, pode-se afirmar que o marketing político cumpre, pois, a função de idealizar e concretizar uma forma de fazer política, criando laços consensuais imaginários entre candidato e eleitor. A reprodução imediata da tradução dos resultados de pesquisas eleitorais em peças de publicidade não significa em si participação política e muito menos que exista uma democrática e ampla educação política no país. Tem sido recorrente observar que esses consultores trabalham mais para o sucesso performático e eleitoral de suas campanhas do que para a prática política ou mesmo para o avanço das relações democráticas e ou para o exercício do protagonismo reivindicativo dos eleitores.

Nesta direção há uma série de críticas acerca da má representação de demandas sociais promovida pela comunicação política, fato ou questão que deve ser debitado não apenas na mídia política, mas também nos partidos políticos (Wattemberg, 1998; Delarbre, 2000; Miguel, 2002). No marketing político brasileiro, com a tentativa de desfazer a ruptura que afasta os cidadãos dos candidatos, cria-se uma engenharia de representação simbólica por segmentos e temas aparentemente democráticos e inclusivos, porém, não escapa da ambivalência de mascarar a diversidade cultural. Cria-se, com isso, por vezes, uma dissonância entre as propostas que são representadas na mídia e os governos, levando a política à mera teatralização dos anseios populares.

Como já foi salientado, esses consultores buscam compreender as formas de pensamento e de julgamento de cada segmento social para atuar pedagógica e didaticamente com maior eficiência. Com- 
Marketing e Educação Política

preender o humor, o ódio, as emoções diante da política é uma tarefa interpretativa fundamentada em leituras teóricas, bem como na contratação de apoio técnico em diversas áreas desde as ciências humanas à neurociência e dramaturgia. Buscam entender não apenas o que os eleitores fazem com aquilo que chega até eles, mas como respondem às campanhas de acordo com seus modos mais amplos e anteriores de ver e viver o e no mundo. Em outras palavras, essa interpretação busca compreender as reações e as percepções da população frente à política e, em aspecto mais geral, compreender influências de outras matrizes, desenvolvendo análises de cenários e estratégias de mídia publicitária de forma a influir no comportamento eleitoral.

É curioso perceber, por fim, que tal entendimento é muito próximo ao que inúmeros cientistas da educação já sinalizaram quanto à necessidade de adequação de currículos escolares e metodologias, de acordo com o público e demanda de determinada comunidade. Por exemplo, considera-se que o currículo urbano pode operar sem nenhum sentido em um grupo rural e vice-versa. No que tange aos conteúdos (programas políticos) com os quais esses consultores trabalham, bem como o material didático utilizado para viabilizar a interação entre as mídias e os receptores, seja por meio de jingles, comerciais, materiais impressos ou virtuais, chama-se atenção para o fato de que são discursos e materiais midiatizados que se relacionam diretamente com um receptor que já possui referências e parâmetros de julgamento e de classificação. Se cada qual tem um ponto de vista, todos possuem um estoque de categorias de pensamento que permite olhar, analisar e ser seduzido ao que é proposto no universo da política midiatizada. Seguindo a expertise da área, sabem que os leitores, ou receptores, não são esponjas de artefatos simbólicos. Fazem uso de um conhecimento prévio do público alvo a fim de garantir o sucesso de uma comunicação midiática?

\section{A Estratégia e o Conteúdo do Comício Eletrônico: o dar, o receber e o retribuir}

Na campanha de Edmilson Rodrigues (PSOL) para prefeito da cidade de Belém - Pará, em 2012, as caminhadas e os eventos de rua como panfletagens, comícios, carreatas e bandeiraços tinham uma importância central devido ao reduzido tempo de televisão do candidato. Contudo, os consultores das campanhas presidenciais apontavam que, a ação pública envolvendo a presença de um contingente amplo de pessoas tem sido trocada pelo comício eletrônico através da propaganda eleitoral na televisão, na internet e no rádio.

Em certa medida, tais fatos estão relacionados a um contexto no qual “[...] a mídia se transformou, até certo ponto, na grande mediadora e mediatizadora e, portanto, substituta de outras interações coletivas" (García-Canclini, 2008, p. 289). Numa direção próxima, Jesús Martín-Barbero e Germán Rey (2001) afirmam que a televisão contribuiu na 
modulagem e na deformação de sensibilidades e dos modos de construção dos imaginários e das identidades sociais, a partir de uma hibridação de formas de enunciações, narrativas e gêneros televisivos.

Mas não apenas isso que nos interessa aqui; é importante salientar que a própria estética dos programas, os estilos de narrativas e as enunciações de propostas são próximos aos padrões televisivos correntes no Brasil, como telejornais, visitas em residências, histórias de vida, clipes, entrevistas e programas de auditório. Em outros termos, esses consultores utilizam referências estratégicas já utilizadas por demais segmentos midiáticos com o objetivo de ampliar a compreensão e a apropriação dos conteúdos elencados nas propagandas eleitorais por parte dos eleitores.

Recorrentemente, os consultores de marketing político expõem na televisão lugares e situações importantes na história de vida de seus candidatos, apresentam escolas, professores, igrejas, casas em que moraram, depoimentos de familiares, tomando café da manhã com seus filhos, brincando com netos e animais de estimação, muito próximo ao que se vê em programas de grande audiência na televisão. Trata-se de uma adequação de performances aos gêneros televisivos presentes no cotidiano populacional. Embora a campanha de Belém tivesse uma performance de rua muito visível, munidas de bandeiras, placas nas casas, praças e ruas, carros de som, pessoas que andavam com adesivos colados nas roupas, a televisão era o elemento de maior profusão dos conteúdos e das ideias da campanha.

Entretanto, nos últimos tempos, a relação entre a televisão e a política - e não só a TV, mas também o rádio e a internet - foi alterada. Parte significativa da política tradicional, dos espaços públicos e partidários, deu lugar a um modo diferente de ver e viver a política. O processo de mediatização ampliou o número de pessoas que tem acesso aos conteúdos políticos bem como alterou as performances dos agentes e da ação política para atrair mais interessados. Contudo, sabe-se que são formas de interesse atravessadas por uma tendência festiva. Ou seja, observa-se uma espetacularização da política, na qual, busca-se assemelhar a instituição e os agentes em peças de entretenimento.

Em Belém, os militantes das principais candidaturas iam até às portas das emissoras assistirem aos debates em telões pendurados em trios elétricos preparados pelas próprias campanhas. No dia seguinte, as cenas eram apresentadas nos respectivos programas eleitorais como se os candidatos, tal como algumas celebridades, tivessem torcidas organizadas, por meio das quais, as candidaturas buscavam mostrar e medir forças e prestígios entre si e junto à população.

Corroborando a ideia, para Patrick Champagner (1995; 1998), essa adequação da política e dos políticos aos formatos de entretenimento correntes da televisão mudou a natureza do capital necessário para conquistar sucesso na política. Trata-se não somente de uma personali- 
Marketing e Educação Política

zação do poder, mas trazer para o centro do fazer político um conjunto de profissionais que promovam a adequação entre a política e as performances que atraem a atenção do público (eleitor, receptor, cidadão), no entanto, sem despertar interesse para o aprofundamento de questões ideológicas dos diferentes partidos. Isto é, os conteúdos repassados nesses momentos de entretenimento novamente apresentam ser superficiais, ligeiros, sem enfrentamento ou com propostas aprofundadas. A imagem e a performance de cada candidato são priorizadas em detrimento de uma discussão complexa sobre os problemas locais, regionais e nacionais. Ademais, quando convém, os políticos se revestem de uma aura de trabalhadores ou administradores, batalhadores ou revolucionários, representam papéis sem se ocuparem de demonstrar os caminhos para o alcance de suas proposições. Ajustam-se às demandas de seus possíveis eleitores construindo pouco a pouco a percepção de que a política se resume às propostas vazias ou com poucas chances de realização.

Por outro lado, num tom mais contundente, Martín-Barbero e Rey (2001) observam a forte relação entre ação política e ação publicitária. Sugerem que o desencantamento da política transformou o partido em um aparelho-meio especialista em comunicação, o carisma em algo fabricado por uma engenharia midiática e o povo em público. Para Cándido Monzon (2001), a crescente espetacularização da política responde à necessidade dos políticos e dos partidos chamarem atenção para suas vozes e causas com maior eficiência, tendo em vista que perderam para os meios de comunicação espaço de influência. Objetiva-se manter a capacidade de mobilizar as percepções populares acerca dos diversos assuntos tendo como estratégias programas afinados com uma estética televisiva há muito consagrada e aceita pela população.

Contudo, parecem ter receio em apresentar formatos inovadores ou conteúdos polêmicos que dispersariam ou não seriam compreendidos pela grande maioria da população. Mais uma vez a reflexão aprofundada está ausente dos programas em seus conteúdos e em suas proposições. Em síntese, o compromisso pedagógico do marketing político é com a compreensão de propostas que resultem em vitória eleitoral. Observa-se um uso recorrente do maniqueísmo nas peças publicitárias para facilitar a apreensão sem garantir uma problematização mais aprofundada de temáticas e questões que envolvem os agentes e as instituições políticas.

Pode-se assim compreender que a espetacularização política é uma estratégia socializadora difusa relacionada à certa soberania que os meios de comunicação conquistam como agentes educativos nas últimas décadas. Nesta direção, vale lembrar uma situação emblemática do argumento acima descrito. Em 2012, na eleição para prefeito de Belém, as campanhas de Zenaldo Coutinho (PSDB) e Edmilson Rodrigues (PSOL) duelaram quanto à quantidade e aos prestígios de artistas famo- 
sos e populares que os apoiavam. No segundo turno, com tempo de mídia igual entre as candidaturas, as semelhanças de formatos midiáticos puderam ser melhor identificadas, dentre elas, duas: a) visita às casas e aos bairros e b) utilização de artistas famosos. Os consultores das campanhas criaram uma identificação com o formato midiático reconhecido e praticado em outras mídias, como a trajetória de visitas às casas de telespectadores para presenteá-los e realizar sonhos. A exemplo disso, temos na televisão brasileira os apresentadores Luciano Huck, Gugu (Augusto Liberato), Netinho de Paula.

Por conseguinte, tudo leva a crer que a presença de famosos nos programas eleitorais busca associar prestígio e reconhecimento legítimo às imagens, propostas e projetos políticos. Este formato é bastante comum na televisão brasileira e em organismos internacionais, nos quais artistas famosos emprestam às campanhas suas reputações prestigiosas que conquistaram junto à população com finalidade de influir sobre as percepções e as posturas. Salvas as diferenças entre programa político-eleitoral e programa de variedades, quando vão às casas, esses apresentadores escutam declarações positivas muito próximas àquelas ouvidas pelos candidatos em Belém em suas visitas às casas de eleitores numa espécie de circuito da dádiva, na conceituação maussiana (Mauss, 2003).

Marcel Mauss (2003), ao analisar o dom, as trocas simbólicas realizadas nas sociedades arcaicas, identificou um sistema de reciprocidade, no qual existia uma tripla obrigação, a saber: dar, receber e retribuir. No contexto midiático analisado por este artigo, é possível observar uma narrativa que expõe a realização do sonho de ser visitado e de ganhar o presente. Para isso, recebe-se o apresentador com todas as honras da casa, retribuindo-lhe com declarações apreciativas e histórias capazes de ampliar a audiência ${ }^{8}$. Eduardo Cintra Torres (2014, p. 70) considera que, na televisão, o dom é uma estratégia que visa "[...] reforçar uma relação afetiva e de proximidade com a audiência”, alimentando "[...] o prestígio e a superioridade moral do doador e do mediador televisivo e confirma o lugar hierárquico superior de ambos em relação ao donatário e espectador".

Ademais, essa estratégia presente nos programas eleitorais é referendada, confirmada e reproduzida em muitos dos trabalhos dos consultores políticos. Ela tem como objetivo estabelecer uma transferência de poder. Busca difundir um sentimento de unanimidade, agregar certo consenso referente às personalidades políticas e as celebridades. Sob a conivência dos famosos, o candidato estaria ungido a conquistar a legitimidade junto aos eleitores. Trata-se de uma tentativa de transferência de energias que vinculam fãs, apreciadores, admiradores e devotos às celebridades apoiadoras dos candidatos e das propostas políticas.

Em outros termos, ao expor na televisão essa troca simbólica entre candidatos e eleitores, os consultores políticos buscam replicar o 
Marketing e Educação Política

mesmo sentimento vivido pelos visitados para os demais eleitores que assistem ao programa eleitoral. Ademais, se por um lado, é possível identificar essa estratégia do marketing político, como um mecanismo de aproximação entre o eleitor e o candidato, de colocá-los em posições similares, de falsear as hierarquias entre os agentes; ao mesmo tempo verifica-se que a personalização da política constrói a imagem de um eleitor recebedor da atenção do candidato sendo que na real política a correlação inversa seria mais correta.

Por fim, a midiatização de imagens que visam representar as relações de amizade entre o candidato e o eleitor traduzem o rompimento dos limites entre a função pública das candidaturas para se tornar uma troca de favores entre amigos e correligionários. A partir de uma inspiração nas reflexões de Roberto DaMatta (1986) sobre os discursos igualitários e as hierarquias no Brasil, pode-se afirmar que as narrativas das campanhas produzidas pelo marketing político reiteram um jogo de oscilações que visa colocá-los nos planos da igualdade e da identificação mútua. Trata-se de uma teatralização da horizontalidade, uma reprodução de um discurso igualitário, entre agentes da política em um país hierarquizado.

\section{Interpretando a Cultura: o caso da religiosidade}

No caso das campanhas dos candidatos a prefeito de Belém - Pará, em 2012, observou-se uma série de expressões das religiosidades nos programas eleitorais, desde declarações de apoio de pastores e padres às menções ao Círio de Nazaré. O mesmo foi observado nos materiais de mídia das campanhas presidenciais, tais como os usos de imagens de cruzes, casais heterossexuais em situação de cerimônia de casamento na igreja, mulheres trajadas com roupas específicas para mães de santo, menção da palavra fé e o nome Deus em jingles, slogans e textos interpretados por candidatos e apresentadores dos programas. Em resumo, na maioria das campanhas eleitorais no Brasil, a religiosidade compõe alguma parte das narrativas. Ela é midiatizada como se expressasse sentimentos essenciais do conjunto da população, trazendo no bojo das imagens e dos discursos conceitos impregnados no senso comum sobre as religiões, especialmente cristãs, como compaixão, solidariedade, força, honestidade, compromisso, devoção, crença, fé, coragem, valentia, aliança, capacidade de superação, dentre outros.

A exemplo disso, nas pesquisas, em 2012, o candidato a prefeito de Belém Edmilson Rodrigues (PSOL) oscilava para baixo na busca por seu terceiro mandato e, em 2010, Marina Silva (PV), candidata a presidente da república, crescia e buscava uma vaga no segundo turno. Nos respectivos programas na televisão, Edmilson citou o apóstolo Paulo para dizer que combateu o bom combate, porém guardou a fé no sonho socialista e Marina citou o enfrentamento entre os personagens bíblicos Davi e Golias.

866 Educação \& Realidade, Porto Alegre, v. 41, n. 3, p. 853-872, jul./set. 2016. 
Com o mesmo sentido, as duas campanhas relacionaram a fé à capacidade de superação e coragem, chamando a população a agir com valentia e compaixão na busca pela virada eleitoral. Embora filho de uma mãe evangélica e tendo apoio de importantes lideranças evangélicas da cidade, Edmilson não possui religião e sua campanha foi duramente atacada por segmentos evangélicos ligados aos seus adversários, especialmente pelo fato de seu partido defender políticas públicas de direitos humanos para as populações LGBT (Lésbicas, Gays, Bissexuais, Transgêneros) e de religiões afro-brasileiras. Por sua vez, Marina Silva, evangélica, não articulou sua campanha às principais igrejas brasileiras, seja por ter uma militância ligada ao movimento ambiental mais propenso à laicidade do Estado ou, talvez e principalmente, porque os principais apoios evangélicos já tinham sido negociados com as campanhas de Dilma Rousseff (PT) e José Serra (PSDB). Marina teve um discurso difuso quanto ao apoio dos seus parceiros de fé. Porém, nos debates e entrevistas, afirmou de forma contundente suas posturas e pensamentos religiosos contrários à ampliação de direitos relacionados ao aborto, ao casamento entre pessoas do mesmo sexo e à política de drogas.

Fazendo uso das estratégias das pesquisas de opinião, do entretenimento bem como explorando a dimensão da religiosidade entre os brasileiros, os mestres do marketing político realizam o que Ortiz (2006) nos ensinou. Interpretam a cultura política do brasileiro, deslocando as manifestações culturais de sua esfera particular e as articulam a uma totalidade que a transcende. Interessadamente, a prática política do brasileiro passa a ser regida pela festa, amizade, bondade e espírito de comunidade. Mais do que isso, no marketing político brasileiro, o eleitor é retratado como um ser valente diante das adversidades, um cristão que está ciente de seus deveres e tem direito a uma vida melhor e digna. Caberia a eles também fazer uso da fé e da esperança na efetivação do vínculo social com o candidato empreendendo a melhor escolha ainda que seja combatida por adversários.

Luís Arnaldo Campos e Francisco Cavalcante, consultores da comunicação política da campanha de Edmilson Rodrigues em 2012, defendem que essa representação do candidato nos braços do povo, nas baixadas (bairros da periferia da cidade), é um retrato da realidade. Muitos militantes da campanha também afirmavam que o Edmilson é um cara acessivel, sempre esteve junto aos mais pobres, gosta do povo. Entretanto, as estratégias de midiatização da campanha dele se assemelham nesses aspectos às demais. Juntas, mesmo que concorrentes, cumprem o papel de representação, de construção simbólica e de difusão de valores sobre vínculos de harmonia entre agentes políticos. Assim, retratar a política no enlace do privado e do público, pautada na intimidade, na amizade, na proximidade entre agentes e nas expressões da fé, busca popularizar um modo de interação entre os agentes, os candidatos e os eleitores. Difunde um perfil de campanha pautada novamente em certa inversão de hierarquias como bem lembrou Roberto DaMatta (1997). 
Marketing e Educação Política

\section{Considerações Finais}

Mais de vinte anos se passaram desde a primeira campanha para eleições diretas para presidente. Vivemos uma democracia jovem que vem tateando sua trajetória com avanços e recuos. As gerações mais antigas devem se lembrar dos momentos festivos e uma engajada mobilização na conquista e realização das escolhas de seus governantes, tanto em cargos executivos como legislativos. A Constituição Federal de 1988 foi um marco na história política recente no Brasil. Ainda que existam aspectos controversos desde período, a liberdade de organização para novos partidos políticos, a consolidação do HGPE (Horário Gratuito de Propaganda Eleitoral), a emergência de novas tecnologias da informação e da comunicação marcaram uma maneira difusa de educação política ou ao menos uma forma de visibilidade desta dimensão da vida de todos. Neste sentido, passados esses anos, é oportuno um investigar analítico sobre o que se conquistou até agora em termos de compreensão e representações acerca das campanhas eleitorais via marketing político.

As reflexões deste artigo emergiram de uma pesquisa inédita sobre as relações entre o marketing político e a educação. Por isso, a aproximação introdutória das temáticas foi realizada com o devido cuidado para não produzir associações ligeiras. Inspirado na relação entre a sociologia da educação e a sociologia da cultura, disciplinas que se ocupam da identificação e análise das maneiras de ser, agir e pensar dos indivíduos e as estratégias das instituições socializadoras, buscou-se examinar e discutir o trabalho dos consultores na construção de representações em seus aspectos culturais. Partiu-se do pressuposto de que refletir sobre as mídias políticas é uma forma de desvelar um dos mecanismos de formação de consensos bem como uma maneira de identificar estratégias de construção e articulação de categorias de pensamento, acerca da dinâmica política no Brasil. Assim, foi possível apreender as construções difusas de uma socialização política operada por esses cada vez mais influentes intérpretes do Brasil.

Primeiramente, observou-se a relevância das pesquisas eleitorais para orientação da produção das campanhas e para a adequação de performances midiáticas dos candidatos. Na construção de um programa eleitoral, verificou-se uma persistência dos gêneros midiáticos de amplo reconhecimento, apoiadas no conceito de entretenimento e na relação paradoxalmente mágica e eficiente entre famosos e populares. Identificou-se ainda, que na apresentação dos candidatos e nas suas relações com eleitores o trabalho do marketing político favorece um entendimento de que os políticos estão ao lado do povo, são amigos do povo, possuem intimidade e conhecem a realidade de todos; embora tratados como celebridades, os candidatos estendem a mão para os menos favorecidos, numa demonstração de sabedoria, benevolência e superioridade; ademais, observou-se uma forte presença da religiosidade

868 Educação \& Realidade, Porto Alegre, v. 41, n. 3, p. 853-872, jul./set. 2016. 
nas peças de campanha como expressivo instrumento mobilizador das populações brasileiras e belenenses. Desse modo, o marketing político utiliza os recursos de identidade de mais fácil apreensão com a finalidade de viabilizar associações positivas e criar condições para apropriação dos conteúdos políticos.

Não é por acaso que o uso da fé e das visitas às casas dos eleitores nos programas de campanha compõem uma das estratégias do marketing para retratar os vínculos sociais harmoniosos e cúmplices entre os agentes da política, especialmente os eleitores e os candidatos. Essa tática compõe uma didática que visa estabelecer uma noção de intimidade, comunhão, entre os agentes, uma aproximação simbólica entre eles, de modo que os demais eleitores abram-se para uma audiência e atribua cumplicidade ao que é dito e proposto nos programas eleitorais. Com isso, contribuem para uma reafirmação de uma interpretação de que, na condição de eleitor, o brasileiro é um ser ordeiro, hospitaleiro, receptivo e acolhedor. Tudo leva a crer que a estratégia tem como finalidade vincular os eleitores e os candidatos em uma única identidade horizontal e igualitária, mostrando que são um a cara do outro. Como diria Ortiz (2006), unificam agentes que em circunstâncias diversas estariam separados.

Tudo leva a crer ainda que os consultores de marketing político agem como intérpretes do Brasil, praticando uma ação educacional e socializadora difusa da população no tocante às suas disposições de habitus em sua dimensão política e identitária. Segundo Elias Evangelista Gomes (2015), os consultores podem ainda atuar como interventores culturais, capazes de interferir nos entendimentos sobre aspectos mais específicos das culturas. Em outros termos, esses profissionais operam como intérpretes de nossa cultura política buscando estimular trocas simbólicas com a população, que podem consolidar representações também sobre a prática política e a nação.

Sazonalmente presentes nas emissoras de TV e Rádio, durante semanas, a cada ano eleitoral, o marketing corrobora a imagem de uma cidadania também esporádica; uma cidadania que se reduziria a uma presença pontual nos dias das eleições e não no acompanhamento contínuo do fazer ou não fazer dos mandatários. Ou seja, o engessamento de uma prática política em momentos de campanha, subliminarmente difunde uma forma fragmentada do fazer política. A exemplo disso, quantas vezes não escutamos que a grande maioria da população não se recorda de seus candidatos nas últimas eleições. Ao lado de novelistas, escritores e antropólogos, eles são importantes agentes que formam opinião sobre o que foi, o que é, e o que pode vir a ser a política no Brasil. Contudo, utilizando uma didática própria e estratégias publicitárias tais como jingles, enquadramento visual e textual - perdem a oportunidade de fazer uso das campanhas como um verdadeiro instrumental pedagógico para a democracia representativa. 
Esses profissionais trabalham como se fossem ora mestres, ora analistas, ora conselheiros. Buscam ensinar os políticos a serem entendidos. Todavia, desenvolvem textos, peças e imagens que visam orientar o eleitor e o cidadão a compreenderem o funcionamento de certo tipo de política, ideias e ou propostas de participação eventual, sem o devido estímulo crítico, reflexivo e continuado. Operam também como filtros de práticas culturais nacionais ou locais - como a religiosidade de modo a criar afinidades entre as perspectivas dos políticos e as perspectivas dos eleitores. Fazem uma leitura interessada da cultura popular como se ela existisse de forma unitária e homogênea, sem profundos conflitos ou amplas contradições - um cidadão ordeiro, trabalhador e de fé.

De fato, são poderosos veículos, mediadores interessados e dedicados a uma produção, difusão e, por certo, uma educação política no Brasil. Assim, esses profissionais, nos últimos anos veem contribuindo significativamente para uma parte da educação política na democracia representativa brasileira, por suas competências comunicativas, pelo domínio de técnicas de auscultar a população e por suas habilidades em elaborar estratégias e conteúdos. Por fim, contraditoriamente, observa-se que a maioria desses agentes educativos a serviço de interesses eleitorais de seus clientes, reproduzem uma didática, valores e noções que pouco a pouco, os vocábulos política e político, para as novas gerações, podem assumir um sentido pejorativo. Com tantas promessas não cumpridas, a ação desses protagonistas não são necessariamente entendidas como legítimas; ao contrário, a disputa eleitoral deixa de ser um embate saudável de trocas de argumentos para ser interpretada como falsas e escusas artimanhas dos dominadores ${ }^{9}$.

Recebido em 18 de novembro de 2014 Aprovado em 07 de março de 2016

\section{Notas}

1 A pesquisa que subsidiou este artigo contou com o apoio da Fundação de Amparo à Pesquisa do Estado de São Paulo (FAPESP), através do processo 2014/09056-1.

2 Não se tem a pretensão de discutir todos os aspectos dos dados empíricos. As reflexões acerca deles estão restritas às perguntas a serem discutidas e respondidas para os objetivos exclusivos deste artigo.

3 Para o entendimento socioantropológico acerca do histórico do marketing político no Brasil cf. Castilho (2014a; 2014b) e Scotto (2004).

4 Edmilson Rodrigues governou a cidade de Belém entre 1996 e 2004, eleito e reeleito pelo Partido dos Trabalhadores (PT). Em 2005, transferiu-se para o Partido Socialismo e Liberdade (PSOL). Em 2006, foi candidato e não se elegeu ao governo do Estado. Em 2010, foi eleito deputado estadual com maior votação do estado do Pará. Na eleição de 2012 para prefeito, no segundo turno, perdeu a disputa para Zenaldo Coutinho (PSDB). 
5 Tendo em vista a contribuição pretendida pela pesquisa que originou este artigo, não se teve como objetivo compreender ou discorrer sobre as especificidades da composição do eleitorado. Em suma, o foco da pesquisa esteve orientado para o trabalho dos consultores e suas estratégias pedagógicas.

6 Observa-se uma série de valores nas campanhas relacionados, por exemplo, ao trabalho, à autoridade dos mais velhos ou à jovialidade, à formação ética, às posturas vinculadas à honestidade, à justiça e à solidariedade. Neste artigo, aborda-se a presença da religiosidade como estratégia para retratar os vínculos sociais entre os candidatos e os eleitores.

7 A este respeito cf. Setton (2010).

8 Para aprofundar as reflexões sobre a dádiva, cf. Mauss, 2003; Sabourin, 2008.

9 Este artigo é resultado de pesquisa apoiada pela Fundação de Amparo à Pesquisa do Estado de São Paulo (FAPESP), através do processo: 14/09056-1.

\section{Referências}

BOURDIEU, Pierre. Estruturas Sociais e Estruturas Mentais. Teoria e Educação, Porto Alegre, n. 3, p. 113-119, 1991.

BOURDIEU, Pierre. Meditações Pascalianas. Rio de Janeiro: Bertrand Brasil, 2001.

CASTILHO, Sergio Ricardo Rodrigues. 'Marketing Político': a construção social do "mercado eleitoral” no Brasil (1954-2000). Rio de Janeiro: 7 Letrasj, 2014a.

CASTILHO, Sergio Ricardo Rodrigues. Etnografando Elites no Brasil: dilemas éticos e metodológicos de uma pesquisa sobre "marketing político" no final do século XX. In: CASTILHO, Sergio Ricardo Rodrigues; SOUZA LIMA, Antonio Carlos; TEIXEIRA, Carla Costa (Org.). Antropologia das Práticas de Poder: reflexões etnográficas entre burocratas, elites e corporações. Rio de Janeiro: Contra-Capa, 2014b. P. 119-219.

CHAMPAGNER, Patrick. Les Sondages, Le Vote et La Démocratie. Actes de La Recherche en Sciences Sociales, Paris, n. 109, p. 73-92, oct. 1995.

CHAMPAGNER, Patrick. Formar a Opinião: o novo jogo político. Petrópolis: Editora Vozes, 1998.

DaMATTA, Roberto. Explorações: ensaios de sociologia interpretativa. Rio de Janeiro: Rocco, 1986.

DaMATTA, Roberto. A Casa \& a Rua: espaço, cidadania, mulher e a morte do Brasil. Rio de Janeiro: Rocco, 1997.

DELARBRE, Raúl Trejo. El Império del Marketing Político: cuando las imágenes desplazan a las ideas. América Latina Hoy, Salamanca, n. 25, p. 15-22, ago. 2000. DIZARD, Wilson. A Nova Mídia: a comunicação de massa na era da informação. Rio de Janeiro: Jorge Zahar Editor, 2000.

FIGUEIREDO, Rubens. O Marketing Político: entre a ciência e a razão. In: FIGUEIREDO, Rubens (Org.). Marketing Político e Persuasão Eleitoral. São Paulo: Fundação Konrad Adenauer, 2000. P. 11-41.

FERNANDES, Florestan. Ensaios de Sociologia Geral e Aplicada. São Paulo: Pioneira, 1960.

FERNANDES, Florestan. Sociologia da Educação como 'Sociologia Espacial'. In: PEREIRA, Luiz; FORACCHI, Marialice Mencarini. Educação e Sociedade. São Paulo: Companhia Editora Nacional, 1971. P. 06.

Educação \& Realidade, Porto Alegre, v. 41, n. 3, p. 853-872, jul./set. 2016. 
GARCIA-CANCLINI, Néstor. Culturas Híbridas: estratégias para entrar e sair da modernidade. São Paulo: Edusp, 2008.

GOMES, Elias Evangelista. Os Consultores de Comunicação Política no Brasil e a Produção da Crença. In: NUMMER, Fernanda Valli; FRANÇA, Maria Cristina Caminha de Castilhos (Org.). Entre Ofícios e Profissões: reflexões antropológicas. Belém: GEPTA/UFPA, 2015. P. 97-125.

GOMES, Neusa Damartini. Formas Persuasivas de Comunicação Política: propaganda política e publicidade eleitoral. Porto Alegre: EDIPUCRS, 2000.

MARTÍN-BARBERO, Jesús; REY, Germán. Os Exercícios do Ver: hegemonia audiovisual e ficção televisiva. São Paulo: SENAC/SP, 2001.

MAUSS, Marcel. Sociologia e Antropologia. São Paulo: Cosac Naify, 2003.

MIGUEL, Luiz. Os Meios de Comunicação e a Prática Política. Lua Nova, São Paulo, v. 6, n. 55-56, p. 155-184, 2002.

MONZON, Cándido. Opinión e Imagen Pública, Una Sociedad 'Bajo Control'. Palabra Clave, Bogotá, n. 4, p. 9-25, 2001.

ORTIZ, Renato. Cultura Brasileira e Identidade Nacional. São Paulo: Brasiliense, 2006.

SABOURIN, Eric. Marcel Mauss: da dádiva à questão da reciprocidade. RBCS, São Paulo, v. 23, n. 66, p. 131-138, 2008.

SCOTTO, Gabriela. As (difusas) Fronteiras Entre a Política e o Mercado: um estudo antropológico sobre o marketing político, seus agentes, práticas e representações. Rio de Janeiro: Relume-Dumará: Núcleo de Antropologia da Política - UFRJ, 2004.

SETTON, Maria da Graça Jacintho. Família, Escola, Mídia: um campo com novas configurações. Revista da Faculdade de Educação USP, São Paulo, v. 28, n. 1, p. 107-110, 2002.

SETTON, Maria da Graça Jacintho. A Educação Popular no Brasil: a cultura de massa. Revista USP, São Paulo, n. 61, p. 58-77, mar./maio 2004.

SETTON, Maria da Graça Jacintho. Mídia e Educação. São Paulo: Contexto, 2010.

SETTON, Maria da Graça Jacintho. Socialização e Cultura: ensaios teóricos. São Paulo: AnnaBlume, 2012.

TORRES, Eduardo Cintra. Ensaio sobre o dom na televisão. Análise Social, Lisboa, n. 210, v. XLIX, p. 56-72, 2014.

WATTENBERG, Martin P. The Decline of American Political Parties. Cambridge (Mass.): Harvard University, 1998.

Elias Evangelista Gomes é professor do Instituto de Ciências Humanas e Letras da Universidade Federal de Alfenas (ICHL-UNIFAL-MG), coordenador do Laboratório de Educação e Cultura (LEC-UNIFAL-MG).

E-mail: eliasgomesbh@yahoo.com.br

Maria da Graça Jacintho Setton é professora da Faculdade de Educação da Universidade de São Paulo (FE-USP), coordenadora do Grupo Práticas de Socialização no Mundo Contemporâneo (GPS-USP).

E-mail: gracaset@usp.br

872 Educação \& Realidade, Porto Alegre, v. 41, n. 3, p. 853-872, jul./set. 2016. 